\title{
Epistemic justice through ontological reclamation in pedagogy: Detailing mutual (in)fallibility using inseparable categories
}

\author{
Siseko H. Kumalo
}

Philosophy Department, University of Pretoria

jdd@up.ac.za

(Received: 1 March 2018; accepted: 24 August 2018)

\section{Abstract}

Impulsive uses of collective memory to rally support for decolonised education, establishing clear divisions through binary oppositional thinking, have been characteristic of the student movement. Analysing the binaries that constitute the decolonial turn, I highlight misconceptions of decoloniality that facilitate the erasure of oppositional voices in decolonisation. Misconceptions of decoloniality manifest as the dismissal of all so-called non-African knowledge as colonial. I subsequently caution against the perverted inversions of power in knowledge production in Higher Education in South Africa and interrogate positions that I perceive to be recreating fundamentalisms in the quest for decolonised education. Using a decolonial critique that frames education as emancipatory, I argue for the impossibility of separable categories. I conclude by raising two questions, both of which require further investigation: What is the role of Higher Education in South Africa today? Does decolonial thinking in praxis displace assumptions that continue to perpetuate and maintain coloniality in the South African academy?

Keywords: decolonisation, curriculum reform, Higher Education and the decontextualised learner

\section{Introduction}

Higher education in our context has been framed by the White Paper 3 of 1997 and subsequent legislation such as the Higher Education Act of 1997 as a social institution that ought to function to redress historical injustices. Contemporarily, these aspirations have been articulated as a form of epistemic justice through the scholarship of philosophers working in the field of philosophy of higher education (see Almeida \& Kumalo, 2018; Metz, 2018; Morreira, 2017). These scholars have articulated the role of higher education in repelling historical injustices, using African communal values (Metz, 2018) and have revealed continued injustice through ontological reframing and the co-optation of Indigeneity into (de)colonial strategies (Almeida \& Kumalo, 2018). My aim in this paper is twofold: first I reveal how hegemonic voices in the \#Fallist movement silenced dissident voices, through adopting, by way of mimicry, the hegemony established by colonial masculinities; second, I 
evaluate the extent to which higher education delivers on the aims of redressing historical injustices. In working through the second evaluative move I use a theory of mutual (in)fallibility that fosters epistemic justice, as demanded by students through the \#Fallist movement. The concept of mutual (in)fallibility is altered from the work of Keet, Zinn, and Porteus (2009) who argue for a pedagogy of mutual vulnerability in post-conflictual societies such as ours. The infraction here serves to re-articulate the pedagogical responsibility of the intellectual/pedagogue/professor, in that through her or his praxis, there are ethical and moral boundaries which should not be blurred and allowed to interrupt the pedagogical journey of the student. It is on the basis of these ethical and moral boundaries that the concept is infracted from vulnerability to (in)fallibility. ${ }^{1}$

Framing higher education as an institution that delivers on social justice is a move that comes from Brighouse's (2003) reading of John Rawls's theory of justice which maintains that justice is the primary virtue of all social institutions. Framing higher education as an institution that should uphold the virtue of justice comes from an engagement with the work of Welsh and Savage (1977) who have problematised how the university in South Africa has deepened racial and ethnic divides. I anticipate an objection from those who maintain that there has been a significant amount of change in the higher education system of South Africa. I grant this, although, since they were writing at the height of segregation and apartheid in South Africa, the concerns raised by Welsh and Savage (1977) continue to have currency today because of the aspirations of the governing legislation in the sector. In line with the vision of a new South Africa, legislation has sought to ensure that higher education functions as a means of bridging the gaps and cleavages that were instituted by apartheid. This aspiration of closing social fissures, derived from years of colonial domination that culminated in the apartheid regime, is witnessed in the foreword to White Paper 3 of 1997 wherein Professor Bengu, then minister of education, wrote that " $[\mathrm{t}]$ he higher education system must be transformed to redress past inequalities, to serve a new social order, to meet pressing national needs and to respond to new realities and opportunities" (p. 1).

In articulating how higher education ought to function as a social institution that is geared towards redressing historical injustice in the first section of the paper, I trace how the Difference Principle, which is developed in the work of Rawls and which undergirds a liberal constitutionalism, can be understood as synonymous with coloniality which is premised on modernity. This appraisal foregrounds a critique of the liberal constitutionalism that was contested by the \#Fallist movement. The move that equates modernity with coloniality is rooted in a decolonial analysis and substantiated by the scholarship of Grosfoguel (2007, 2013) and Tlostanova and Mignolo (2009). In revealing the politics of recognition and denial, I argue that the progression of the \#Fallist movement, in silencing dissenting voices, recreated the same essentialising modes of oppression that it sought to oppose. In the second section I deal with the question of how the \#Fallist movement pressed the contemporary academy to re-imagine a curriculum from the locale of the Indigenous Being. I do this using

Mutual (in)fallibility denotes the presuppositions that the intellectual and the student both bring to the pedagogical journey. The parenthesis denotes how these beliefs may be perceived as infallible at first glance, but when interrogated further, prove to be socially constructed biases which influence how we interact with the world around us, either holding views that limit our social position or broaden said position. 
the concept of the decontextualized learner developed by Boughey and McKenna (2015; 2016). To resolve this tension, in the third section, I use the impossibility of separable categories as developed by Ndebele (1994). My aim here is to nuance the decolonisation debate through centring the role of education and its emancipatory potential.

\section{Rawlsian justice for education in historically unequal societies}

In order to situate my discussion on social and epistemic justice through education, I begin by detailing the Rawlsian theory of justice, which is framed in Rawls's (1958) scholarship as "justice as fairness" (p. 164). This analysis is undertaken with the intention of deciphering whether the principles of justice as fairness can be applied in the South African context. My appraisal of Rawlsian justice is done to markedly situate the contributions of the \#Fallist movement that contested (neo)liberal conceptions of justice.

Rawls's theory of justice is premised on the Original Position and the Difference Principle. The Original Position is constituted by the Veil of Ignorance which, when used effectively, allows men ${ }^{2}$ to structure society to afford equality of opportunity to all. The Veil of Ignorance assumes that those who enter behind the Veil are ignorant of who they might be outside of the Veil and subsequently structure society to ensure the equality of all (Daniels, 2000). The Difference Principle, which is the second move that Rawls makes in his theory, maintains that by structuring society through fairness in the distribution of resources, such as wealth, status, and other social goods - the concept of justice as desert-we can begin to posit a theory of justice that is both universal and abstract. Justice as desert bridges social inequality by asserting that people ought to get what they deserve rather than unfairly benefiting from filial ties or talents for which they have not worked (Slote, 2017). Justice as desert thus aims to resolve inherent social inequalities by appealing to the deeds of a person and encouraging a spirit of conscientiously working towards the betterment of society instead of merely selfish interests. Subsequently, social inequalities, as dictated by the Difference Principle, should be structured to benefit the least well-off in society.

A liberal ${ }^{3}$ conception of society and its attendant structures and social institutions is derived from Rawls's theory of justice, which posits justice as fairness. To frame justice as fairness is, according to Rawls, premised on the assumption that we agree (there is consensus) on matters concerning individual freedoms and how social institutions attend to the dysfunction of these through liberal constitutionalism, what Rawls (1987) later called an overlapping consensus of our society.

However, before moving on to conduct the appraisal of Rawls's theory, I wish to sketch in summative form the workings of an overlapping consensus. Rawls (1987) maintained that an

\footnotetext{
2 I use the term men deliberately since the politics of the \#Fallist movement manifested through men taking the lead in conversations that were organised and initiated by women and gender-non-conforming peoples. The masculinist logic and gendered language of the times of Rawls permeated the \#Fallist movements (see http://www.thedailyvox.co.za/unheard-voices-lgbtq-people-student-movements/). My use of this phraseology is done in an attempt to subvert the role of, and reveal how, men in the \#Fallist movement acted as the centre of enunciation.

Here liberal is used as it has developed and influenced political paradigms and systems of governance.
} 
overlapping consensus should be achieved through the structuring of social institutions using democratic constitutionalism, which treats all men with fairness. To treat all men with fairness assumes that everyone is equal before the $\mathrm{law}^{4}$ and that all men are able to judge what is good, through the use of practical reason (Daniels, 2000). An objection which may be levelled against an overlapping consensus can be found, through interpretation, in the work of MacIntyre (1988) who addressed in detail the question of whose rationality is used in defining individuals as possessing practical rationality/reason. MacIntyre raises this question after foregrounding how we live in highly complex societies that shape and influence our thoughts and perceptions of the world we inhabit. The aim here, however, is not to exhaust the debate of rational reason since I deal with this contention later in the paper, but, rather, to showcase the shortcomings of the premise which supposes that we act from a universally accepted and dominant conception of reason and rationality. This shortcoming foregrounds the decolonial critique which has been levelled against western coloniality/modernity.

Daniels's (2000) assessment of an overlapping consensus suggested that this consensus should distinguish between private and public (otherwise defined as political) domains. This distinction allows for a pluralism that coalesces differences on non-political positions as they manifest from person to person as a result of their personal reflective equilibrium. Pluralism thus defined is necessary since it secures the maintenance of the liberalist order which is embedded in a democratic constitutionalism developed by Rawls (1987). What we miss, however, in the pursuit of a liberal society is the notion of divergent and contradictory views of what society ought to look like. I contend, therefore, that it was these divergent views that were being expressed by the \#Fallist movement, which took issue with the nature and form of the contemporary university in South Africa.

These divergent views have been addressed by Standish (2003) who has emphasised that education is a personalised, historically, and politically constructed concept. This position was substantiated by Ramose (2014), who considered Socratic notions of truth and justice and argued that this contradiction arises from two competing external truth positions that then require a politico-juridical adjudicator. These externally competing truth positions that birth differences are constitutive of the cultural, political, and social situatedness that make the social institution of education a contentious institution as Standish (2003) has argued. Social positionalities, which are premised on culture, political and social situatedness, inform how we interact with, make meaning of, and understand our worlds. Cultural specificities inform how knowledge is constituted in different contexts, a point that has been emphasised in the work of Minh-Ha (1989) and has received credible uptake in the scholarship of thinkers in the social epistemological circles. At this juncture we can begin to question whether the Rawlsian conception of justice truly works for the South African context, but definitive conclusions to this end would be premature at this point.

The distinction between private and public domains emphasised by an overlapping consensus obscures the work of social epistemologists, specifically in relation to education. Social

Another qualification which cannot go unmentioned comes from Mills (2009) who details the place of race in a Rawlsian conception of justice. It is crucial for my reader to bear in mind that the subject, for whom equality before the law was sacrosanct, is the white male, in accordance with the Rawlsian conception of justice. 
epistemologists have argued for the use of experiential knowledge in curriculation strategies (see Popkewitz \& Brennan, 1997) and the development of theoretical tools that assist in articulating the challenges of specific locales. Mohanty (1993), who wrote on the epistemic status of cultural identity, is instructive in this case. She maintained that cultural identity can be harnessed to speak back and build new conceptions of knowledge which have been neglected because of systems of power, domination, and oppression and the imposition of colonial modes of knowing and being. If we are to take seriously the distinction made in Daniels's (2000) work, we would lose sight of the potentialities that lie in using experiential knowledge for the purposes of curriculating from a position that seeks to redress historical traumas and violences in the South African context.

Locating our curriculum in the contextual specificities of cultural identities responds meaningfully to the charge made by Nyoka (2013), who critiqued South Africa social theory for its continued importation of theoretical frameworks from the north. These concerns have been echoed in the work of decolonial writers Tlostanova and Mignolo (2009) as well as Grosfoguel (2013) who argued that the structure of knowledge in westernised universities is premised on privileging knowledge produced in the west. ${ }^{5}$ This reality is based on the colonial legacy that established educational models that reflect mimetic pedagogical praxes that continue to be the bastions of coloniality even in a post-colonial condition such as South Africa's. Through the continued importation of theory, we bear witness to the cultural erasures which have been vehemently contested through the actions of students in 2015, through the \#Fallist movement.

What is revealed through the actions of the \#Fallist movement are the tensions maintained through social structures, therefore necessitating the contestation of the overlapping consensus developed by Rawls. This contestation is premised on the rejection of liberal constitutionalism, which maintains social structures of domination and the systematic exclusion of Blackness from institutions of higher learning in the country. The \#Fallist movement has pressed the South African university and academic to conceptualise anew how they teach and what they teach. I subsequently develop the argument below that the actions of the \#Fallist movement should be understood as challenging conceptual schemas of justice such as Rawls developed in A theory of justice (1971) since students seem to understand these conceptions of justice to be perpetuating domination.

\section{Modernity/coloniality: The role of liberal constitutionalism}

I wish to highlight that in detailing the critiques of liberal constitutionalism my aim is neither to contest nor challenge the constitutional framework that has facilitated democracy in South Africa. Rather, I wish to reveal the salient discourses in the student movement that frame the contemporary constitutional framework as a mode of selling out. Selling out, as it has been used by contemporary discourses of the \#Fallist movement, connotes collusion between the new ruling Black elite and the former oppressors, the white supremacists who sought to maintain their position of power even after the demise of apartheid. This discourse is

5 I do not use a capital letter here since I am writing from a decolonial perspective. 
predicated on the demand that the land be returned to ensure the economic emancipation of the majority in the country. This demand is in direct correlation with the demands of the decolonial/Indigeneity studies movement in Canada which demands the restitution of land as a means of fostering epistemic justice and thus substantive constitutional justice.

Furthermore, we cannot evade the reality that many Black South Africans remain in poverty, in under-resourced schools, landless and disenfranchised from economic participation, rendering them unable to substantively participate in the democratic processes of the country. This brief contextual analysis nuances the critique of the Difference Principle as levelled by a student movement that contests a (neo)liberal ordering of society.

In the process of dispossession, invasion, and colonialism what became of Indigenous/Black subjectivities, was later to be framed through the lens of apartheid, a logical progression in the continuum of oppression. Apartheid cannot, however, be understood outside of the dialogical nature in which blackness and whiteness exist in colonial societies. Rutherford (1990) has pointed out that Homi Bhabha, who uses a Hegelian dialect to analyse oppression, makes the claim of culture mutating and re-formulating thus creating a synthesis that Bhabha termed Third Space Hybridity. Arriving at Third Space Hybridity requires the thesis, understood as southern African precolonial societies, with the antithesis marked by the colonial moment of settler arrival. Hegelian dialectics inform us that from the thesis and the antithetical tension we arrive at the final position which is synthesis, which can here be interpreted as Bhabha's Third Space Hybridity which is constituted by the amalgamation of both the cultures of the oppressed and the oppressor, creating a cosmopolitan reality located in modernity. The cosmopolitan reality of modernity in the scholarship of the decolonial movement of South America (Grosfoguel, 2007; Tlostanova \& Mignolo, 2009; MaldonadoTorres, 2006; Mignolo, 2011; Nakata, Nakata, Keech, \& Bolt, 2012), which in recent times has been adopted by the decolonial turn in South Africa evinced through the scholarship of Vorster and Quinn (2017) has been framed as synonymous with coloniality. Framing modernity as synonymous with coloniality reveals the chronology of modernity as emanating from the histories of the exploitation of Black cotton-farm slaves of the southern states of America, the indentured labourers of the sugar cane plantations of the south coast and the migrant labour in the gold and diamond mines of the Witwatersrand and Kimberly respectively, of South Africa. ${ }^{6}$

Grosfoguel (2007) argued that it is through the narrative of enlightenment that European powers are led to the colonialist project. This claim is premised on the link that Grosfoguel made between Descartes's cogito ergo sum, and what later becomes "I conquer therefore I am" (Grosfoguel, 2011, p. 6) which presses whiteness and coloniality to dispossess, enslave, and oppress subaltern ${ }^{7}$ bodies. Further, modernity as synonymous with coloniality highlights the intersectionality in the (neo)liberal, patriarchal, capitalist global economy which was birthed by systems of exploitation, domination, and oppression. Dispossession, exploitation, and violent masculinities are linked to liberalism through the rights to private property which

Given the focus and aims of this paper, I am cautious about mapping out this historical progression. The term subaltern is used in this paper, as developed by Spivak (1988) who asks, in the title of her seminal contribution, Can the Subaltern Speak? 
are vehemently defended by capitalist society. Using capitalism, and numerous political structures, practices, and attitudes that prop up liberal democracy remain unquestioned and intact, as has been argued by Dahl (1970). This brief summative sketch brings into full view the project of questioning an uncritical adherence to liberal ideology, which was contested by the \#Fallist movement. However, my aim here is not to detail the decolonial turn, which has currently mesmerised the South African academe. Rather, it is to demonstrate how the cosmopolitan reality of modernity which is synonymous with coloniality gave rise to the displacement, erasure, and silencing of voices interpreted as dissenting from the formal consensus that governed the decolonial project among the \#Fallists.

Understanding modernity as synonymous with coloniality allowed the \#Fallists to make the move that contests the legitimacy of liberalism in our context and foregrounds the premises that contest liberal constitutionalism in a post-colonial society. In challenging liberalism in the South African context, it is critical to note that the principles of liberalism assume ontological homogeneity, represented in the Rawlsian formulation that all those who enter behind the Veil of Ignorance are equal before the law. A further assumption contends that all persons are capable of rational reason, as determined by western conceptions of rationality and reason-an assumption which, when pressed from a decolonial perspective, begins to wither.

Our context interpreted through a decolonial lens suggests that what we are dealing with, rather, are hierarchies of being, constituted through a heteronormative patriarchy, which defines the white cis-gendered male knower as the legitimate knowledge-producer, capable even of speaking on behalf of all subaltern bodies. As a result, the legitimate knower is the patron of these violent masculinities derived from colonialism which become imbued in subaltern masculinities as they attempt to define their personhood using resistance strategies that mimic the colonial masters. The act of mimicry among the \#Fallists culminated in the creation of violent masculinities as they became the spokespeople of all in the \#MustFall movement. Through the imposition of violent Black masculinities we witnessed the relegation of all other knowers, who may have been perceived as threatening these gendered power systems, to the periphery in a fashion that silences and displaces voices of dissent. This was witnessed in the \#MustFall movement, with queer bodies, women, and disabled bodies contesting the violence with which these masculinities manifested in the movement. ${ }^{8}$

These hierarchies of being substantiate the claim that we are not dealing with equal persons who enjoy the same liberties enshrined in the constitution. Hierarchies of being that place priority on violent masculinities, given the co-option of violence by patriarchy, have been challenged in critical African feminist thought by Gqola (2007), who has suggested that for us to claim to be truly living in a democratic society, women along with men ought to be accorded the equality that enables each person to truly realise her or his agency without having to live in fear of violence that aims to regulate the autonomy of each. In a panel discussion an activist from Rhodes University contended, according to Henderson (2017), that "it's
painful for us to come here and be spoken about. Erased, and then spoken about" (n.p.). 
In tracing how dispossession through the colonial encounter facilitated modernity in our context, I aim to reveal the historical imbrications that facilitated the birthing of violent contemporary masculinities. In the context of the \#Fallist movement, these violent masculinities asserted themselves as the spokespeople of the movement, thus silencing alternative voices through the active work of dismissing queer, feminised, and dissident voices in the movement. My aim thus, is to reveal the modalities in which the Rawlsian Difference Principle undermines the objectives of attaining substantive justice through tracing how inequality in our context is not to the benefit of the least well-off. Undermining substantive justice is envisaged in how masculinities in the \#Fallist movement silenced, erased, and marginalised dissenting voices underscoring the contentiousness of applying an overlapping consensus in our context. Liberal constitutionalism, premised on modernity, that I have shown to be synonymous with coloniality, operates through displacements that silence and continue to oppress feminised bodies. Having revealed the intersectionalities between patriarchy, violent masculinities, and capitalism, all of which function to undermine a genuine commitment to decoloniality in our context, I now consider the questions posed by MacIntyre (1988) in the title of his book, Whose justice? Which rationality?

In what follows I clarify how these questions centre the importance of the propositions made by Wiredu (1998) who, in pointing to the need to decolonise African philosophy and religion, reveals the angst of adopting western forms of knowledge, and substantiates the need to challenge the notion of an overlapping consensus through the case-study of the decontextualized learner.

\section{The decontextualized learner/native of nowhere}

In detailing the notion of the decontextualized learner, I must qualify the ways in which MacIntyre's (1988) question can be instrumentalised by radical voices in the curriculum reform debate, essentially recreating the same modes of oppression that decolonisation and decoloniality claim to be working against. He makes the argument that we can understand the thinking of a philosopher only once we have considered her or his social and cultural context. Understanding the cultural and social context from which a writer speaks requires that we understand that no knowledge framework is universal, but, rather, that each knowledge framework is provincial (Grosfoguel, 2007). To frame knowledge as provincial does not disqualify the legitimacy of that episteme, but connotes an understanding of the functions of ahistoricising, and apoliticising knowledge.

A tradition that was adopted by colonialism and continues to the modern day, frames (and has framed) knowledge as ahistorical and apolitical while divorcing it from its social and cultural context, therefore substantiating the claim of universality. This tradition substantiated the actions of colonial settlers, masters and thinkers alike, in rendering Indigenous knowledges obsolete, doing what Mudimbe (1988) called the anthropologising of Indigenous epistemes through their classification as "gradual, retarded and backward" (p. 3). Classifying subaltern epistemes thus allowed for the erasure of these knowledges and this resulted in epistemic violences that began at the inception of the European colonialist project. 
Some decolonialists subsequently use this historical instrumentalisation of anthropology as a way of classifying all knowledge that emanates from the west as imperial, colonial, and of no use in the context of decolonisation. Envisaged through this strand of the decoloniality discourse is a move which aims to raze colonial knowledges and institutions to the ground, without systematically attempting to understand the contextual specificities from which the contemporary university functions. I should not be misunderstood as being an apologist of colonialism and white domination; what I am attempting here is an historical reading that shapes contemporary knowledge frameworks and subsequently complicates the position of radical decolonialists. Fundamentally, I wish to reveal the banality and trite intellectual laziness of those who claim to be radically decolonising the university without a contextual understanding that refutes separable categories.

A critique that can be levelled against Grosfoguel (2013) when he wrote about the structure of knowledge in westernised universities rests on how his contribution here does little to complicate the decolonial debate. Nuancing the decolonising project entails an awareness of how these knowledges, while provincial in their nature, are useful in the project of refashioning and reconceptualising subaltern knowledges which were, in part, erased by the colonial project. What I aim to stress through a nuanced understanding of the decolonial project is how we can begin to create ecologies of knowledges that transcend and meaningfully decolonise the canon. My aim here then is to press Grosfoguel (2011) on his claim of transcending the canon as an act of decolonising that challenges the binary thinking that claims that any and every knowledge framework developed in the west is colonial. While it is necessary to acknowledge that these knowledges were used in the past to colonise and control subaltern bodies, it is also equally important to remind ourselves of Bhabha's Third Space Hybridity (see Rutherford, 1990). Through conceptually understanding the post-colony using Third Space Hybridity, I wish to complicate the essentialist moves made by radical proponents of decolonisation, through revealing that both the subaltern and their oppressors work together in defining and re-defining their identities. ${ }^{9}$

The process of defining and re-defining identities brings me to the consideration of the decontextualized learner. Boughey and McKenna (2015) have problematised how the university discourse propagates a conception of knowledge-making as apolitical, ahistorical, and devoid of social and cultural practices. Through problematising this culture of knowledge-production in the university, these scholars highlight how colonial discourses continue to permeate the university since the contemporary South African university is organised along the structure of the westernised one. Second, these scholars point to how this mode of framing places the problem solely at the doorstep of the learner, resulting in the deficiency discourse that frames subaltern bodies in the contemporary university as lacking and in need of capacitation. What is implicit in the deficiency discourse is the assumption that knowledge is apolitical, which, in turn, leaves contemporary modes of teaching and learning unchallenged. It is this ardent adherence to the classification of knowledge as an apolitical,

I should not be misunderstood here as simply glossing over a number of complications and realities that strain at the existence of the post-colonial subject. However, I wish to stress how the colonial condition, while defined by violence-epistemic, political, ontological and social—is a space that forces cross-cultural contamination from both the colonised and the coloniser. 
ahistorical, and socially and culturally devoid project that has been challenged by the student movements in recent times. However, the challenge brought to the academy against academics by student movements has not come without its own problematics.

To charge the student movements with being riddled with problematics is premised on how the student movement has classified any dissent from the radically defined notion of decolonisation as fundamentally in contradiction to the emancipatory aims pursed by the \#Fallists. These clearly defined strategies of decolonisation, which classify the Historically White University as a bastion of coloniality in its entirety, give rise to the logic that anyone who deviates from these definitions is a clear enemy. Defining dissenting voices as enemies poses numerous dangers, with some of these dangers witnessed in the \#MustFall protests of 2016. Through a discourse that framed dissenting voices as enemies, ${ }^{10}$ South Africa witnessed students pitted against each other, all in the name of a call to radically decolonise the university. Essentially, through a radical outlook that defined oppositional voices as the enemy, a strategy that led to the social death of dissenting voices, the student movement in its decolonising agenda recreated the same fundamentalisms that it sought to uproot.

While some components of the decolonial movement are indeed legitimate, it is necessary that in the process, the academe remain critical and open to the wisdom of thinking. This requires that we reveal the provinciality of each knowledge system, while being receptive to lessons from history and acknowledging where provincial knowledges may be useful in developing and refashioning contemporary epistemes. This process reiterates the questions posed by MacIntyre (1988) to define the rationally reasonable person. Implicit in MacIntyre's (1988) questions, for the purposes of this analysis, is that we analyse the possibility of delivering on a just education system that is decolonised and transformed through the use of strategies that aim to decentre knowledge that continues to masquerade unquestioned as hegemonic imperialism. I believe that Wiredu's (1980) contention that we decolonise African philosophy and religion might shed some light on the question of a just and decolonised education system that decentres Eurocentric modalities.

\section{The politics of knowledge and emancipation through education}

In Whose Justice? Which rationality? MacIntyre (1988) highlights the political nature of knowledge through revealing that knowledge is constituted through a tradition. The term tradition as used here denotes the cultural mores and social values that an individual inherits from her or his social context that frames the ways in which the individual interacts with the world. MacIntyre's (1988) work is necessary to revealing how the contradictions which are inherent in the student movement manifest themselves through the use of historical memory used in the decolonial movement as a rallying call. Eyerman (2001) has maintained that after twenty to thirty years, a generation draws from historical memory as a mode of recounting what socio-political liberties remain unachieved in contemporary society.

10 See Samanga's (2016) analysis of how the \#MustFall movement split into two camps. 
Using historical memory, the \#Fallist movement sought to fashion a struggle that fought against what students felt had not been attained in a democratic South Africa. However, the challenge with this historical lens, that then inspires the new generation, is that it fails to consider that the contemporary dispensation is one that is rooted in a democracy and not in an oppressive regime governed by laws of segregation and exploitation. Thus, the contradictions within the movement are premised on an attempt to recreate, in a democratic state, a regime that is repressive. Subsequently, we see the notion of a clear enemy identified by Mazwai (2016) in the essentialised spaces of oppression (that invoke colonial tropes that continue to exist in the university) in order to imagine state machinery as oppressive. In Mazwai's rendition of "Jikijela" the voice-over in the song makes the claim that "we understand and we know clearly who the enemy is." The binary mode of thinking that we witnessed in the 2016 academic year fed into the classification of a liberal constitutionalism as a system which undermines the place of Blackness in South Africa. Wiredu (1998) has pointed out that the role of philosophy should be understood as a consistent questioning and critical examination of the conceptual frameworks upon which the thought of a culture is premised. In keeping with this definition of what philosophy ought to do, I wish to examine the culture upon which the South African Black experience rests.

Blackness in South Africa has had a history of resistance against domination since the inception of colonialism. While there exists a multiplicity of identities in South Africa, evinced through the numerous ethnicities, there is a shared history of resistance against white minority rule and the oppression of all Black peoples of the country. This history and memory were used in the decolonial calls to rally all students behind the incentive of decolonising the university. Ndebele (1994), in his South African Literature and Culture, notes the impossibility of separable categories that deny all South Africans positions of absolute innocence. This claim can be substantiated through Bhabha's Third Space Hybridity, which claims that the cultures of the oppressed and the oppressor work interchangeably and in consort to create new identities, which, as discussed above, form a cosmopolitan identity. I must insist here that the inherited cosmopolitan identity does not take away from the legitimacy and reality of the historical violence that necessitated resistance in the first instance. Gqola (2001) has made the argument that the new dispensation created a sense of tokenistic inclusion, as Black South Africans were continually reminded of their historically subjugated role. This history was used by the student movement as a rallying call for decolonisation of higher education, but subsequently ended up recreating the same modes of oppression that it sought to dismantle, as detailed in the discussion above.

These differences that Gqola (2001) noted inspire further articulation and introspection in order to understand how decolonisation ought to function in South Africa. I wish to posit that these differences present the contemporary academic with a generative space for curriculum reform in a pedagogy of what I call mutual (in)fallibility that could flourish in parallel with the "mutual vulnerability" of Keet, Zinn, and Porteus's (2009) article title. Differences premised on history allow us to confront historical traumas which ought not to be repeated. This articulation of education unearths the emancipatory capacity of education. Framing a pedagogy of mutual vulnerability as a humanising tool, rests on the assertion made by 
Wiredu (1998) who has argued that decolonisation must refer to due reflection and durable deference if it is to attain the objectives that it sets out to achieve. Prior to making this claim, Wiredu (1998) maintained that decolonisation in African philosophy does not mean forced unanimity among Africans. This assertion substantiates the claim I made earlier in this paper that the project of a uniform conception of decolonisation, with dissenting voices framed as enemies, heralds the dangerous slippage which, momentarily, disrupts essentialisms and fundamentalist positions without dismantling the power structures that create subaltern and hegemonic Beings.

A just education system, which is both decolonised and transformed, requires that the university return to its traditional definition as a space teeming with ideas and contradictory views. This framework allows us to harness the traumas of history while confronting these traumas with a durable deference. If decolonisation is understood properly it signifies the creation of an ecology of knowledges as central to the ethos and culture of the university. Durable deference along with a collegial institutional framework undergirded by the principle of an ecology of knowledges harnesses rather than contests Ndebele's (1994) claim that in a context like South Africa the possibility of separable categories is not only fallible but is also unobtainable. An education system that is decolonised and just, undertakes to reveal the provincialities of knowledges while embracing those elements that can be used in advancing the objective of teaching with the aim of humanising — an objective that is central to a pedagogy of mutual (in)fallibility.

\section{Conclusion}

Decolonialists in South Africa have been at pains to define how and what the act of decolonisation looks like. This has been, in part, given the fact that decolonisation in the country has been led by a student movement that sought to challenge colonial modes of being that continue to define subaltern bodies as the perpetual Other, in constant need of the masters of coloniality to come to their aid. As a result, academics (specifically radical decolonialists across the academy) relinquished their pedagogical responsibility, first and foremost, in order to be regarded as being in solidarity with the calls for decolonisation as demanded by students. This relinquishing of responsibility, what I interpret to be a dereliction of duty, created narratives and conceptual understandings of decolonisation which are not only dangerous but play further into the discourse of banal binaries. In essence, what I witnessed in the academy was and continues to be an intellectual community that dances to the tune of power while neglecting the honourable duty that calls upon academics to be critical thinkers who inculcate a culture of critical thinking in students. This reality presents us with a critical question that requires further attention and investigation in decolonial scholarship: What is the function/role of higher education in contemporary South African society?

While the move that describes the actions of radical decolonialists as a dereliction of duty might seem egregious to some, it is in fact precisely what academics continue to do through a blind commitment to student calls for decolonisation without a critical examination of the 
context in which we are located. Student calls for decolonisation are indeed worthy and substantiated, as showcased by Boughey and McKenna $(2015,2016)$ through their discussion of the decontextualized learner. The concept of the decontextualized learner reveals how the contemporary university continues to perpetuate coloniality through the apoliticisation and ahistoricisation of knowledge, stripping it of its social and cultural contextualities that frame and create systems of power. Challenging these systems of power, which the decolonial turn in South Africa has set out to achieve, is indeed a legitimate and substantiated cause. However, it is the duty of the academic to guide students in a responsible way by empowering them with the tools with which to dismantle these systems of power. This duty arises from the fact that the academics are responsible for these skewed imbalances of power since they benefit from the status quo subsequently maintaining and perpetuating these systems. This schema of duty gives birth to a second deeper question that demands further philosophical considerations in education: Does decoloniality in praxis shift contemporary imbalances of power in the knowledge production project of higher education in South Africa?

If we are truly to acknowledge the concept of a pedagogy of mutual (in)fallibility derived from the work of Keet et al. (2009), it becomes the responsibility of academics to reveal their role within the broader social structure so as to establish mutuality in a pedagogical schema prefaced by (in)fallibility as a humanising tool. Resigning from this responsibility, which I interpret to be a dereliction of duty, is indicative of an intellectual community that aims to merely tinker with the system while leaving the overarching structure unchanged, unquestioned, and unchallenged. What is required of academics in an historical moment such as ours is a merging of disciplinary expertise with an ethical pedagogical obligation that defines education as a humanising process. It is only through the realisation of the emancipatory potential of education that we can truly begin decolonising and transforming higher education in South Africa.

\section{References}

Almeida, S., \& Kumalo, S. H. (2018). (De)Coloniality through Indigeneity: Deconstructing calls to decolonise in the South African and Canadian university contexts. Education as Change, 22(1), 1-24.

Boughey, C., \& McKenna, S. (2016). Academic literacy and the decontextualised learner. Critical Studies in Teaching and Learning, 4(2), 1-9.

Boughey, C., \& McKenna, S. (2015). Analysing an audit cycle: A critical realist account. Studies in Higher Education, 42(6), 963-975.

Brighouse, H. (2003). Educational equality and justice. In R. Curren (Ed.), A companion to the philosophy of education (pp. 471-486). Oxford, UK: Blackwell.

Dahl, R. A. (1970). After the revolution: Authority in a good society. New Haven, CT: Yale University Press. 
Daniels, N. (2000). Reflective equilibrium and justice as political. In S. Brennan, C. Card, B. Dauenhauer, M. A. Friedman, D. Jamieson, R. Arneson, R. Nagle, J. Nickel, C. Fehige \& N. Daniels (Eds), The idea of a political liberalism: Essays on Rawls (pp. 127-154). Lanham, MA: Rowman \& Littlefield.

Department of Education. (1997). Education White Paper 3: A programme for the transformation of higher education. Pretoria, RSA: Government Printer.

Eyerman, R. (2001). Cultural trauma: Slavery and the formation of African American identity. Cambridge, UK: Cambridge University Press.

Gqola, P. D. (2001). Defining people: Analysing power, language and representation in metaphors of the new South Africa. Transformation (47), 94-106.

Gqola, P. D. (2007). How the "cult of femininity" and violent masculinities support endemic gender based violence in contemporary South Africa. African Identities, 5(1), 111124.

Grosfoguel, R. (2007). The epistemic decolonial turn: Beyond political-economy paradigms. Cultural Studies, 21(2-3), 211-223.

Grosfoguel, R. (2011). Decolonizing post-colonial studies and paradigms of politicaleconomy: Transmodernity, decolonial thinking, and global coloniality. Transmodernity: Journal of Peripheral Cultural Production of the LusoHispanic World, 1(1), 1-40

Grosfoguel, R. (2013). The structure of knowledge in westernized universities: Epistemic racism/sexism and the four genocides/epistemicides of the long 16th century. Human Architecture, 11(1), 73-90.

Henderson, R. (2017, March 9). Report about Fees Must Fall protests at universities stirs up more debate. Business Day. Retrieved from https://www.businesslive.co.za/bd/national/education/2017-03-09-report-about-feesmust-fall-protests-at-universities-stir-up-more-debate/

Keet, A., Zinn, D., \& Porteus, K. (2009). Mutual vulnerability: A key principle in a humanising pedagogy in post-conflict societies. Perspectives in Education, 27(2), 109-119.

Maldonado-Torres, N. (2006). Cesaire's gift and the decolonial turn. Radical Philosophy Review, 9(2), 111-138.

MacIntyre, A. C. (1988). Whose justice? Which rationality? London, UK: Duckworth.

Mazwai, T. (2016). Belede. CD-ROM. Johannesburg, RSA: Universal Music LLC. 
Metz, T. (2018). An African theory of the point of higher education: Communion as an alternative to autonomy, truth and citizenship. In A. Stoller \& E. Kramer (Eds), Contemporary philosophical proposals for the university: Toward a philosophy of higher education. Cham, $\mathrm{CH}$ : Palgrave Macmillan.

Mignolo, W. (2011). The darker side of western modernity: Global futures, decolonial options. Durham, NC: Duke University Press.

Mills, C.W. (2009). Rawls on Racemace in Rawls. The Southern Journal of Philosophy, 47, 161-184.

Mohanty, S. P. (1993). The epistemic status of cultural identity: On Beloved and the postcolonial condition. Cultural Critique, (24), 41-80.

Morreira, S. (2017). Steps towards decolonial higher education in Southern Africa? Journal of Asian and African Studies, 53(3), 287-301.

Minh-ha, T. (1989). Woman, native, other: Writing postcoloniality and feminism. Bloomington: Indiana University Press.

Mudimbe, V. Y. (1988). The invention of Africa. Bloomington: Indiana University Press.

Nakata, M., Nakata, V., Keech, S., \& Bolt, R. (2012). Decolonial goals and pedagogies for Indigenous studies. Decolonization: Indigeneity, Education \& Society, 1(1), 120-140.

Ndebele, N. (1994). South African literature and culture: Rediscovery of the ordinary. Manchester, UK: Manchester University Press.

Nyoka, B. (2013). Negation and affirmation: A critique of sociology in South Africa. African Sociological Review/Revue Africaine de Sociologie, 17(1), 2-24.

Popkewitz, T. S., \& Brennan, M. (1997). Restructuring of social and political theory in education: Foucault and social epistemology of school practices. Educational Theory, 47(3), 287-313.

Ramose, M. B. (2014). Dying a hundred deaths: Socrates on truth and justice. Phronimon, 15(1), 67-80.

Rawls, J. (1958). Justice as fairness. The Philosophical Review, 67(2), 164-194.

Rawls, J. (1971). A theory of justice. Cambridge, MA: Harvard University Press.

Rawls, J. (1987). The idea of an overlapping consensus. Oxford Journal of Legal Studies, 7(1), 1-25. 
Rutherford, J. (1990). The third space: Interview with Homi Bhabha. In H. G. Ders (Ed.), Identity: Community, culture, difference (pp. 207-221). London, UK: Lawrence and Wishart.

Samanga, R. (2016, March 8). From student leader to "sell-out": How Fees Must Fall split in two. True Africa. Retrieved from https://trueafrica.co/article/student-leader-sell-feesmust-fall-protests-split-two/

Slote, M. A. (2017). Desert, consent, and justice. In W. Sadurski (Ed.), Justice (pp. 95-120). New York, NY: Routledge.

Spivak, G. C. (1988). Can the subaltern speak? In C. Nelson \& L. Grossberg (Eds.), Marxism and the interpretation of culture (pp. 271-313). London, UK: Macmillan Education.

Standish, P. (2003). The nature and purpose of education. In R. Curren (Ed.), A companion to the philosophy of education (pp. 221-231). Oxford, UK: Backwell.

The Daily Vox Team. (2016, April 5). The Unheard Voices: LGBTQ+ People in Student Movements. The Daily Vox. Retrieved from http://www.thedailyvox.co.za/unheardvoices-lgbtq-people-student-movements/

Tlostanova, M., \& Mignolo, W. (2009). Global coloniality and the decolonial option, Kult 6 Special Issue, 130-147.

Vorster, J. A., \& Quinn, L. (2017). The "decolonial turn": What does it mean for academic staff development? Education as Change, 21(1), 31-49.

Welsh, D., \& Savage, M. (1977). The university in divided societies: The case of South Africa. In H. van der Merwe \& D. Welsh (Eds.), The future of the university in Southern African (pp. 130-147). Cape Town, RSA: David Philip.

Wiredu, K. (1998). Toward decolonizing African philosophy and religion. African Studies Quarterly, 1(4), 17-46. 